\title{
Libanon: The Coalition of the Unwilling
}

\section{Kajsa Ji Noe Oest}

\section{Hvilken betydning har det for fremtidige fredsbe- varende indsatser, at det var så svært at samle 15.000 soldater til en så ukontroversiel operation som i Libanon 2006?}

Ledende politikere verden over løb i flere dage forvildede rundt og ledte efter 15.000 forsvundne FN-soldater. Særligt FN's generalsekretær Kofi Annan og den finske udenrigsminister Terkki Tuomioja var på overarbejde og rejste EU's hovedstæder tynde i søgningen.

Umiddelbart kan det godt være lidt svært at forstå. Hvordan kan det være, at det ikke er muligt at samle 15.000 soldater til en ukontroversiel fredsbevarende styrke. 15.000 kunne selvfølgelig godt lyde af meget, men set i lyset af, at FN har 192 medlemmer, er det kun ca. 78 soldater pr. land. Sådan kan man selvfølgelig ikke sætte det op. Mange af de 192 medlemslande har ikke muligheder for at bidrage med styrker.

Men mange og særligt de større europæiske lande har kapaciteten og mulighederne for at yde betydeli- ge bidrag til styrken. Alligevel gik der relativt lang tid fra resolutionen, som i sig selv var længe undervejs, blev vedtaget, til koalitionen blev dannet. På trods af at situationen i Libanon var kritisk og kaldte på en hurtig reaktion, og selvom et klart FN-mandat til styrken burde have udløst den fornødne opbakning fra de relevante medlemslande.

Hvorfor var hovedparten af især de større europæiske lande så modvillige? Forklaringen er såre enkel det kunne simpelthen ikke betale sig for hverken de større eller de mindre EU-lande at deltage. Incitamenterne dvs. udsigterne til at opnå nogen egentlige relative fordele eller gevinster ved en deltagelse var for få.

FN havde givet udtryk for, at man gerne så, at omkring 9.000 soldater ud af de $15.000 \mathrm{kom}$ fra EU, men 
det var langt fra sådan, at EU-landene faldt over hinanden for at deltage i styrken. Selvom EU her, pga. USA's tilbageholdende rolle umiddelbart synes at have en mulighed for at gøre sig gældende som udenrigspolitisk aktør.

Samtlige større EU lande var meget tilbageholdne i deres opbakning til operationen. Fx skuffede Frankrig, der havde en ledende rolle i forhandlingerne om våbenhvilen, $i$ første omgang forventningerne om at ville lede styrkerne. Frankrig kom i tvivl og gik fra at tilbyde 2000 til 200 til 400 soldater og så tilbage til de 2000. Og endte med at give udtryk for, at de alligevel gerne vil lede styrken i en deleordning med Italien.

Italien fremsatte trods udsagn om vilje til at lede koalitionen og bidrage med omkring 3000 mand, store forbehold og tvivl. Tyskland påpegede, at man var ophængt i Afghanistan samt at der var etiske problemer i et muligt scenarium med tyske soldater i kamp med israelske. Derfor $\varnothing n s k e d e$ Tyskland kun at bidrage med politi og søværn. Danmark brystede sig af at være klar og parat til at deltage og bidrage, men i realiteten handlede bidraget om et tilbud om en korvette, der aldrig blev brug for, og to missilfartøjer. Med denne ringe interessetilkendegivelse og manglende konsensus er forhåbningerne om, at EU kunne træde i karakter som udenrigspolitisk aktør og udgøre et alternativ til 'the american way', blevet gjort til skamme.
Hvorfor tog det så lang tid at samle soldater til en fredsbevarende operation, som et flertal i FN's sikkerhedsråd bakkede op om. Hvorfor havde fx Frankrig så svært ved at beslutte sig, når man tidligere havde sendt tropper ud i direkte krigshandlinger i Kuwait 1991 og Afghanistan? Det burde umiddelbart ikke have været så svært. Operationen var relativt ukontroversiel sammenlignet med Kuwait 1991 og Afghanistan 2001. Det var ikke en militær intervention, man skulle 'bare' holde ro og orden, og omkostningerne var dermed relativt lave. Regeringsovervejelserne burde derfor have været tilsvarende lette.

\section{Mangfoldige undskyldninger}

Der er mange mulige forklaringer. Undskyldninger for ikke at deltage var mangfoldige. Libanons historie, forholdet til Israel samt at mange af landene er bundet op andre steder som fx Afghanistan og derfor ikke har ressourcerne til at engagere sig endnu et sted.

Andre undskyldninger gik på uklarhed om styrkens mandat i forhold til afvæbning af Hizbollah. Eller bekymring for at de nye FN-styrker ville lide samme skæbne som de eksisterende FN-styrker i Libanon, UNIFIL, der blev sendt ind efter israelske angreb i 1978. De har ikke lavet meget andet end at holde øje med stridigheder lige siden. Eller bekymringer for Syriens reaktion. 
Syriens præsident, Bashar Assad, har sagt, at udstationering af FN-styrker op ad syriske grænser i Libanon vil blive tolket som et fjendtligt træk mod Syrien og overtrædelse af libanesisk suverænitet. Eller tvivl om sikkerhed for soldaterne begrundet $i$ tvivl om Israel vil overholde våbenhvilen, fordi landet forbeholder sig ret til at handle i selvforsvar.

Endelig blev der rejst spørgsmål om angst for en ny borgerkrig i Libanon som i 1970'erne og 1980'erne, da Hizbollah er en del af Libanons samlingsregering. Alle disse grunde er en del af baggrunden for landenes betænkeligheder ved at deltage $\mathrm{i}$ styrken, men hovedforklaringen skal findes et andet sted.

\section{Hvorfor deltage?}

Det handler i bund og grund om, hvorfor stater deltager i fredsbevarende styrker og mere generelt internationale koalitioner? Det kan sidestilles med de overvejelser, der ligger bag deltagelse i alliancer? Det er de samme overvejelser, om man som tredje land skal involvere sig i en konflikt eller ej ved at støtte en af de involverede parter eller mægle den samme overvejelse af fordele og ulemper ved at involvere sig sammenlignet ved fordele og ulemper ved ikke at involvere sig.

Der har igennem tiderne været mange forskellige forklaringer og bud på, hvad der får stater til at vælge at deltage eller ikke deltage i alli- ancer. Nogle af de dominerende forklaringer er, at stater går med i alliancer for at balancere magt i det internationale system, således at stater vil alliere sig med svagere parter mod den stærkeste i det internationale system for at opretholde en magtbalance, så den stærke ikke får for meget magt og truer de andre staters overlevelse. Andre mener, stater balancerer trusler ved at alliere sig med andre mod den, der udgør den største trussel. Endelig er der også forklaringer, der går ud på, at staters valg er betinget af økonomiske eller politiske fordele.

Uanset hvilken man ser som den afgørende faktor, er det svært at finde klare argumenter for nogen af disse i forhold til EU-landenes overvejelser om deltagelse i den fredsbevarende styrke i Libanon.

- For det første er det meget svært at argumentere for eller imod magtbalancerende incitamenter til at gå med i styrken, når verdens eneste supermagt, USA, kun spiller en mindre rolle og ikke deltager i koalitionen. Med mindre man vil se det som en mulighed for EU for at magtbalancere USA, men det viser de med deres tilbageholdenhed ikke tegn på.

- For det andet er det svært at se nogen trusselsbalanceringsincitamenter, hverken negative eller positive, når ingen af EU-landene er udsat for direkte eller indirekte territoriale trusler som følge af konflikten i Libanon. 
- For det tredje er der ikke de store udsigter til økonomiske fordele eller ulemper. Ud over en forholdsvis lille mulighed for økonomiske fordele ved hjælp til genopbygning er Libanon et forholdsvist ligegyldigt land i den sammenhæng, idet det ikke besidder større mængder olierigdomme eller lignende strategisk vigtige ressourcer.

- For det fjerde er de politiske fordele og ulemper ved at gå med eller lade være også til at overse. De indenrigspolitiske fordele ved at gå med var minimale, og nærmest ikke eksisterende. Det eneste der kan argumenteres for er, at der grundet fortsatte uroligheder og heraf følgende tabstal i både Afghanistan og Irak kunne være nogle indenrigspolitiske ulemper ved at gå med. Der har i de fleste EU-landes befolkninger været en tiltagende bekymring for at udsende soldater til konfliktområder.

\section{Magtbalanceincitamentet}

Det, der gør den største forskel her, er fraværet af magtbalanceincitamentet. Den altdominerende supermagt USA spillede for en gangs skyld ikke rollen som initiativtager til operationen. USA har været engageret $i$ at få en resolution igennem og skabe våbenhvile, men fordi Libanon ser Israel som USA's forlængede arm, har Libanon modsat sig amerikanske styrkers deltagelse i en fredsbevarende styrke.
Når USA ikke deltager, forsvinder en stor del af incitamentet for de europæiske stater til at deltage. Under den nuværende magtfordeling i det internationale system med én overordnet supermagt, så vælger lande ud fra en cost-benefit analyse i forhold til deres relation til den overordnede supermagt mere end til de involverede konfliktpartnere, om de skal gå med i større internationale koalitioner

I et traditionelt spilteoretisk perspektiv ses et tredjelands afgørelse om at intervenere i en konflikt mellem stat A og B som et valg mellem at støtte enten stat A eller stat B eller forholde sig neutral. Men i et internationalt samfund med en dominerende supermagt som USA kan der argumenteres for, at denne afgørelse ikke kan ske uden at forholde sig til USA.

Når et land som Danmark vælger, om man skal deltage i krigen mod Irak i 1991, er det svært at argumenter for at det alene var forholdet til Kuwait eller Irak, der gjorde, at Danmark valgte at gå med. Det vil være langt nemmere at finde plausible argumenter for, at det i ligeså høj grad var forholdet til USA. For det første spiller USA en altafgørende rolle i det internationale samfund og har dermed ofte indtaget ledende roller i dannelsen af sådanne koalitioner. For det andet baserer de fleste lande deres afgørelse på en opvejning af interne omkostninger mod de eksterne mulige gevinster ved at gå 
med, og det sted hvor der er størst mulighed for at opnå eksterne gevinster er i relationen til USA.

Mange stater deltager for at få indflydelse, og når den største magt i det internationale samfund ikke deltager formindskes dette incitament. Derfor, når supermagten ikke er engageret tilstrækkeligt, er incitamentet til at gå med ikke stort nok. Stater indretter sig og søger indflydelse og magt i forhold til supermagten i en erkendelse af, at det ikke er muligt at konkurrere kapabilitetsmæssigt med den. De sikrer sig bedst muligt overlevelsesmæssigt i et system med kun en altdominerende supermagt ved at optimere indflydelsen, så deres position er så gunstig som mulig, når engang unipolariteten afløses af bi- eller multipolaritet. Under de forhold, der gør sig gældende i dag med USA som den eneste altoverskyggende supermagt, er det primære, der ligger bag staters afgørelser af om de går med eller ej, ikke magtbalancering, men en cost-benefit analyse i forhold til deres relation til den overordnede supermagt.

\section{USA's manglende rolle}

Hovedpointen i denne artikel er, at USA's manglende deltagelse i koalitionen i Libanon gør deltagelse meget lidt attraktivt for de andre lande. Det kan eksemplificeres ved at se på Danmark. Hvorfor var Danmark så ivrig efter at gå med i Irak efter den amerikanske invasion i $2003 \mathrm{og}$ i Afghanistan i 2001, men ikke her?

Egentlig har der i Danmark altid været et uforholdsmæssigt stort fokus på Mellemøsten, særligt i og omkring Israel. Dette har også gjort sig gældende for den seneste israelske invasion i Libanon. Men selvom man fra udenrigsministerens side erklærede sig parat til at deltage i en fredsbevarende styrke i Libanon, valgte man en Olfert Fischer-løsning - i form af et patruljerende flådefartøj, ligesom i den første Golf-krig i 1990. Det er rigtigt, at størrelsen af Danmarks samlede kapacitet på dette område udgør en væsentligt begrænsning, men i bund og grund er det et prioriteringsspørgsmål, hvor man vælger at bidrage.

Sammenlignes de forskellige koalitioner er der også påfaldende forskelle. Hvad får Danmark mere ud af Afghanistan 2001 og Irak 2003 end af Libanon? Løsningen i 1990 i forbindelse med den første Golfkrig bør ses i lyset af, at den Kolde Krig kun lige var afsluttet og landene, inklusive Danmark, endnu ikke rigtig havde fået fodfæste i de nye strukturer og i høj grad stadig agerede i overensstemmelse med koldkrigssystemet med to altdominerende konkurrerende supermagter.

Under formationen af operationen i Afghanistan 2001 og Irak 2003 gjorde de nye magtstrukturer i det internationale samfund med kun én altdominerende supermagt sig gældende. Derfor var der for Danmark 
klare muligheder for at gøre sig gældende og opnå en indflydelse, man ellers ikke ville have haft ved at deltage i operationer initieret af en supermagt.

Følgelig er incitamenterne meget svagere i Libanon, hvor supermagten USA kun spiller en mindre rolle og ikke deltager i selve operationen. Derfor tillægges selv mindre indenrigspolitiske ulemper, som den tidligere nævnte indenrigspolitiske bekymring for deltagelse i internationale operationer en forholdsvis større vægt. Fordelene ved at gå med var for få i forhold til de indenrigspolitiske ulemper, der altid vil være ved at udsende soldater til konfliktområder. I tilfældet Libanon var der derfor kun direkte omkostninger og mere indirekte gevinster.

Samlingen af FN-styrken til Libanon behøver derfor ikke nødvendigvis ses, som nogen har påpeget, som et opgør mellem EU og USA om fredstyrker. EU har reddet sin ære ved efter nogen tids modstræben at stille med omkring 7.000-8.000 soldater, men EU har endnu engang vist, hvor svært man har ved at blive enige i udenrigspolitiske sager. Libanon-indsatsen markerer ikke, at EU nu for alvor er en afgørende medspiller på den internationale scene. Udsigterne til, at EU træder i karakter i sin udenrigspolitiske rolle og løfter den fredsbevarende byrde uden deltagelse af USA, er således lange.

Spørgsmålet er også om EU overhovedet har en interesse i fredsbevarende indsatser uden USA's deltagelse under de nuværende magtforhold. Ud fra hovedargumentet i denne artikel om andre staters valg af at involvere sig ud fra forholdet til USA og ikke de involverede konfliktparter vil dette kun være i EU's interesse, hvis det sker som et supplement til USA, således at USA har en stor interesse i at EU 'aflaster' USA på området og dermed vil være villige til at 'godtgøre' denne aflastning.

Derfor er det USA som andre potentielle konfliktsteder, fx Somalia, skal sætte sin lid til, hvis de skal gøre sig forhåbninger om indblanding fra større internationale koalitioner som en del af deres løsning.

Kajsa Ji Noe Oest er ph.d.-stipendiat ved Institut for Statskundskab, Københavns Universitet 